\title{
Uma conversa sobre arte e teatro nas prisões com Ashley Lucas
}

\section{A conversation about art and theater in prisons with Ashley Lucas}

Entrevista com Ashley Lucas ${ }^{1}$

Por: Vicente Concilio ${ }^{2}$ Tradução: Vicente Concilio 


\section{Resumo}

Nesta entrevista, Ashley Lucas, professora da Universidade de Michigan, expõe seu processo de trabalho para criar o espetáculo $O$ Visitante Atrás das Grades, em 2004. Ashley detalha também o seu trabalho no Prison Creative Arts Project (PCAP), fundado em 1990 pelo Professor Buzz Alexander, bem como o seu envolvimento com o trabalho cênico nas prisões. Ashley expõe o envolvimento deste projeto com a UNIRIO e o Brasil.

Palavras-chave: Arte nas prisões; teatro nas prisões; processo criativo

\section{Abstract}

In this interview, Ashley Lucas, professor at the University of Michigan, presents her creative process in order to create the play Doin' Time: through the visiting glass", in 2004. Ashley also details her work on the Prison Creative Arts Project PCAP), founded in 1990 by Professor Buzz Alexander, as well as her involvement with theater projects in prisons. Ashley discusses the involvement of this project with UNIRIO and Brazil.

Keywords: Art in prison; theater in prisons; creative process

\footnotetext{
${ }^{1}$ Profa. Dra. Associada de Theatre \& Drama e diretora do Prison Creative Arts Project (PCAP) na Universidade de Michigan (USA). Ela possui um B.A em Estudos de Teatro e Inglês pela Universidade de Yale e Ph.D em Estudos Étnicos e Teatro e Drama da UC San Diego. É membro da Fundação Ford, da UNC Faculty Engaged Scholars Program, and UNC's Institute for Arts and Humanities. Suas atividades de pesquisa e ensino incluem estudos sobre o teatro latino americano, teatro e encarceramento, teatro para a mudança social e assuntos relacionados à atuação, dramaturgia e estudos étnicos.

${ }^{2}$ Prof. Dr. Pedagogia do Teatro no Departamento de Artes Cênicas da Universidade do Estado de Santa Catarina (UDESC). Integra o Programa de Pós-graduação em Teatro (PPGT), e o Mestrado Profissional em Artes - ProfArtes - CAPES, da mesma instituição. Coordenador do GT Pedagogia das Artes Cênicas, da ABRACE - Associação Brasileira de Pesquisa e Pós-graduação em Artes Cênicas. Ator e diretor.
} 


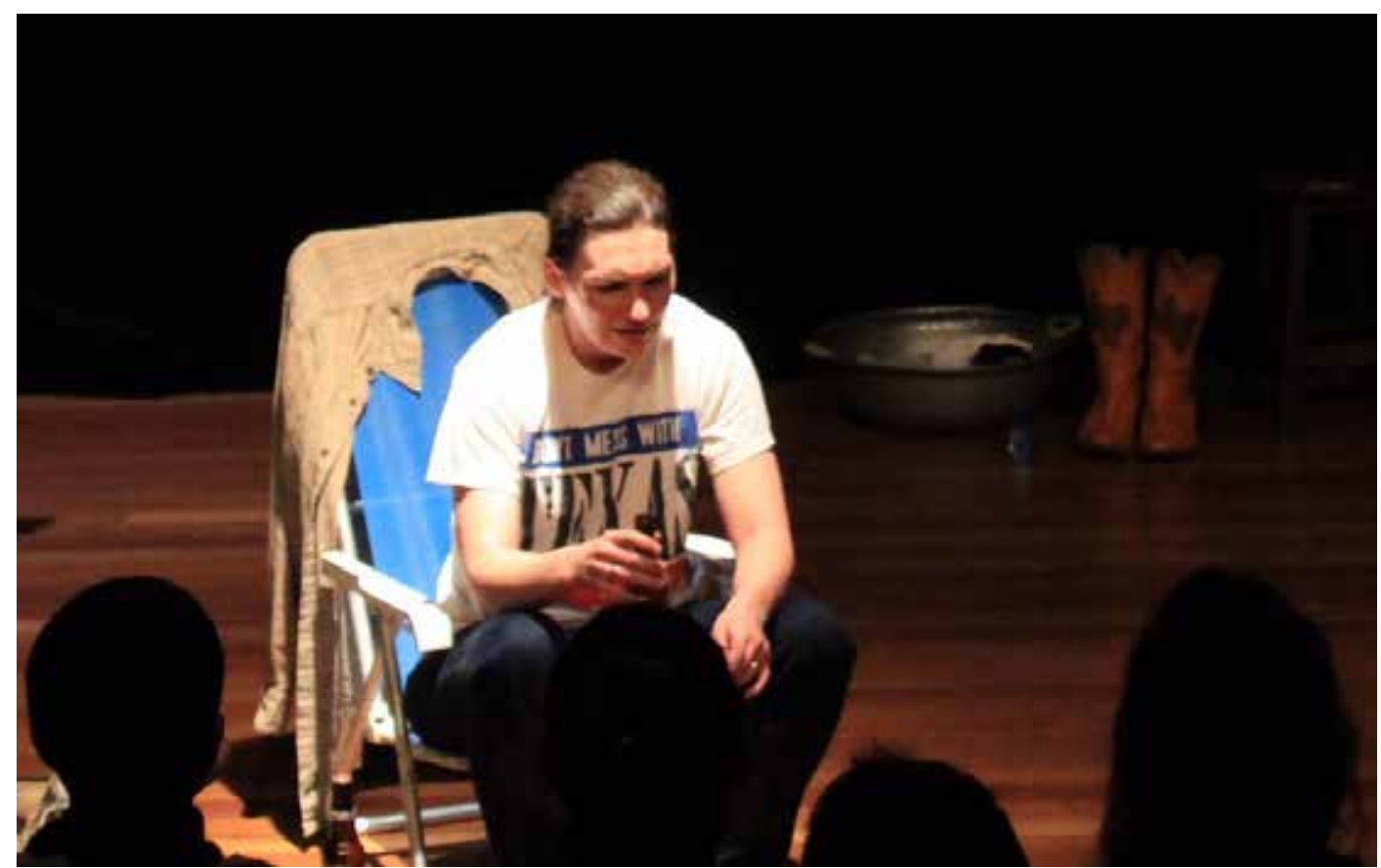

O visitante atrás das grades

Atriz: Ashley Lucas Foto: Alice Cruz

As prisões moldaram todos os dias da minha vida desde os quinze anos de idade

(Ashley Lucas)

Querida Ashley, muito obrigado por seu tempo e disposição em conceder essa entrevista. Eu acho que devemos falar sobre arte, teatro e prisão, e como essas coisas se conectam nos seus projetos artísticos e de pesquisa. Você pode nos explicar como o PCAP funciona?

Bem, o Prison Creative Arts Project (PCAP) foi fundado em 1990 pelo Professor Buzz Alexander na Universidade de Michigan. Ele estava trabalhando com um tipo de prática teatral, que chamamos de teatro para a mudança social com seus alunos, mas nunca teve contato com prisões. Um de seus alunos veio até ele e contou que uma mulher chamada Mary Glover tinha ganho uma ação coletiva contra o estado, dando às mulheres nas prisões de Michigan o direito de ter aulas universitárias pela primeira vez. Até esse momento, os homens presos poderiam receber crédito para cursos universitários, mas as mulheres não podiam. Eles precisavam de professores para começar a ensinar na prisão feminina, e Buzz concordou em ir. No primeiro dia, ele propôs jogos de teatro que envolveram gritos e assustaram a maioria das mulheres no quarto. No final dessa aula, as mulheres que ficaram perguntaram se podiam gritar todas as semanas, porque é isso era proibido em qualquer lugar da prisão.

Buzz percebeu muito rapidamente que este trabalho mudou sua vida e que seus estudantes universitários aprenderiam muito mais entrando em prisões do que ele poderia ensiná-los em uma sala de aula no campus. Ele também queria 
disponibilizar esse tipo de programação para o maior número possível de pessoas na prisão e sabia que ele poderia chegar a mais pessoas encarceradas se ele pudesse envolver mais pessoas na oferta de oficinas de arte nas prisões. Ele então começou a desenvolver uma pedagogia para que seus alunos estruturassem as oficinas de artes semanais. Seus cursos na universidade tornaram-se incrivelmente populares, e os alunos ficaram tão dedicados ao trabalho que muitas vezes continuariam propondo oficinas durante anos, mesmo depois de completarem todas as aulas do PCAP. Muitos permaneceram em Ann Arbor após a formatura apenas para se manter voluntário no Programa.

O Programa cresceu lentamente ao longo dos anos e passou a incluir oficinas de teatro, escrita criativa, artes visuais, fotografia e música. Agora somos o maior programa de artes em prisão do mundo, e enviamos cerca de oitenta voluntários por semana para oferecer workshops em prisões para adultos, centros de detenção juvenil e centros comunitários de pessoas que acabaram de cumprir pena. A maioria dos nossos voluntários são estudantes da universidade, mas artistas locais, membros da família de prisioneiros e pessoas anteriormente encarceradas também se oferecem voluntariamente conosco. Oferecemos workshops semanais em qualquer instalação que fique até a uma hora de distância de Ann Arbor. Nas prisões mais distantes, às vezes oferecemos uma oficina de um dia, mas só podemos oferecer programação regular em instalações próximas da universidade.

Além das oficinas semanais, temos dois grandes projetos anuais. Por duas semanas em março e abril, hospedamos uma das maiores exposições de arte prisional do mundo. Em 2017, exibimos 550 obras de arte feita por 450 artistas. Visitamos todas as trinta prisões para adultos em Michigan para selecionar as obras para a Exposição Anual de Arte feita pelos Prisioneiros de Michigan e oferecer uma análise crítica para os próprios artistas. As obras ficam disponíveis para venda aos preços escolhidos pelos artistas, e todos os ganhos vão diretamente para as contas prisionais dos artistas. O PCAP não faz nenhum dinheiro com a venda das obras.

Outro grande projeto anual é o nosso jornal literário The Michigan Review of Prisoner Creative Writing. O professor Phil Christman, que ensina no Departamento de Inglês, atua como editor da revista e trabalha com uma equipe de estudantes, familiares de prisioneiros e outros voluntários para ler as centenas de inscrições que recebemos por correio todos os anos. Em seguida, publicamos um volume por ano, que contém poesia, prosa e ensaios. Todo escritor que envia algo para nós recebe uma avaliação e incentivo personalizados para continuar escrevendo. Não conheço nenhum outro jornal literário que responda pessoalmente a todos os que são rejeitados. É uma imensa quantidade de trabalho, mas as pessoas na prisão já experimentam rejeição suficiente. Queremos que eles saibam que valorizamos a sua escrita, mesmo que não possamos publicar tudo o que nos é enviado.

Também temos um programa de retorno para as pessoas que saem da prisão. Nós organizamos eventos para incentivá-los a encontrar maneiras de usar suas habilidades artísticas agora que estão fora da prisão, e nós os recebemos em nossas aulas e outros eventos na universidade. Nós fornecemos uma comunidade de suporte e os ajudamos a conseguir alguns dos materiais que eles precisam. 


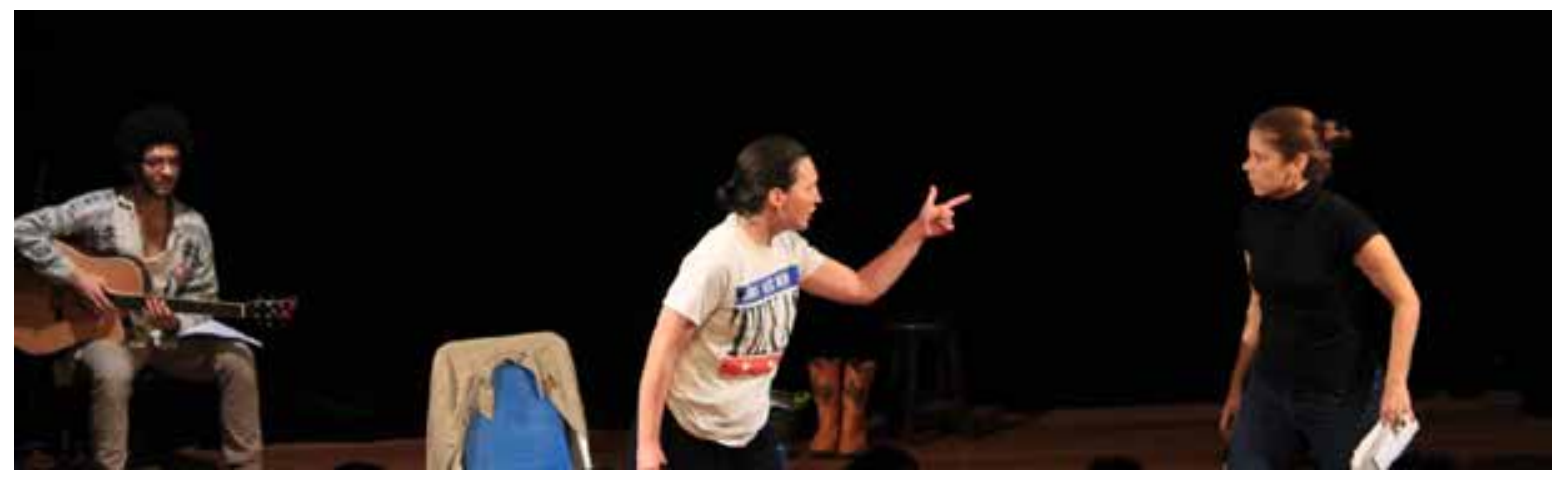

$O$ visitante atrás das grades

Atores: Sergio Kauffman, a Ashley Lucas e Marina Coutinho. Foto: Alice Cruz

Tudo isso é impressionante! Quais são as principais realizações do PCAP, e como você vê o desenvolvimento do PCAP em um futuro próximo?

O PCAP ofereceu atividades e apoio a milhares de prisioneiros nos últimos vinte e sete anos, e também mudou a vida de centenas de estudantes. Acredito que nós conectamos as pessoas mais oprimidas de nosso estado aos estudantes da universidade mais privilegiada da região para formar comunidades significativas entre si. Eu acho que essa é a nossa maior conquista.

O PCAP também expandiu sua programação de várias maneiras significativas nos últimos anos. Nossas oficinas de fotografia começaram em 2015, quando o professor Isaac Wingfield se juntou à nossa faculdade e convenceu o diretor de uma unidade prisional a permitir que ele ensinasse os homens lá a tirar autorretratos. Isso foi revolucionário para nós, porque é muito difícil obter permissão para levar uma câmera dentro de uma prisão dos EUA. Isaac, seus alunos e os homens nessas oficinas criaram imagens notáveis. Kathleen Kelly, que é professora de expressão vocal, está trabalhando conosco pela primeira vez em 2017. Ela está inventando maneiras de oferecer oficinas de música e composições em prisões e estamos muito entusiasmados por podermos expandir nossa programação nesse sentido. As pessoas na prisão nos pedem oficinas de música há anos, mas não podíamos oferecê-las até que tivéssemos um professor que pudesse formar nossos alunos na música.

\section{Por favor, você poderia nos dizer como começou a trabalhar nas prisões?}

Meu pai foi preso quando eu tinha quinze anos. Ele cumpriu vinte anos e cinco meses no Departamento de Correções do Texas e foi solto em 2014. Eu era muito próxima dele e fazia questão de visitá-lo o máximo de vezes possível durante os anos em que ele esteve preso, então, em certo sentido, eu cresci em uma sala de visita da prisão. As prisões são uma parte significativa da identidade da minha família. Comecei a fazer um trabalho real na prisão quando meu pai já estava preso há oito anos. Eu estava concluindo meu Ph.D. no teatro quando foi negada, pela terceira vez, a liberdade condicional a meu pai. Embora eu não pu- 
desse fazer nada para trazê-lo de volta para casa, eu precisava fazer alguma coisa em relação a isso. O que eu sempre soube fazer melhor era teatro, então eu decidi escrever uma peça a partir de entrevistas com pessoas que têm membros da família na prisão. Eu acreditava, até aquele ponto, que eu não conhecia ninguém que tivesse família na prisão. Mas nos Estados Unidos, onde temos mais de dois milhões de pessoas na prisão, isso não poderia ser verdade. Toda pessoa na prisão veio de uma casa e de uma família. Eu queria descobrir onde estavam todas essas famílias e por que ninguém estava falando sobre a experiência de ter um parente querido na prisão. Comecei a entrevistar familiares e escrevi um solo chamado "Doin 'Time: Through the Visiting Glass". Comecei a apresentar a peça em 2004 e tenho viajado com ela desde então. Até começar a receber convites para fazer minha peça nas prisões, eu não sabia que o teatro na prisão existia. As pessoas começaram a me apresentar a outras pessoas que estavam fazendo teatro nas prisões, e minha pesquisa como estudiosa mudou rapidamente. Eu me tornei uma pessoa que estuda o teatro nas prisões e recebeu uma bolsa de pós-doutorado da Fundação Ford para passar o ano escolar 2008-2009 estudando o Projeto Prisão de Artes Criativas (PCAP) da Universidade de Michigan. Meu tempo em Michigan naquele ano levou a uma oferta de emprego para ocupar o cargo de direção do PCAP e também para lecionar teatro na universidade. Comecei a trabalhar lá em 2013 e, ao mesmo tempo, comecei a trabalhar no meu projeto de livro atual, que é sobre o teatro nas prisões do mundo.

\section{Como você desenvolve pesquisas acadêmicas a partir das experiências que você e seus alunos desenvolvem nas prisões?}

Apesar de estar acontecendo teatro nas prisões em todo o mundo, como tem sido há centenas de anos, muito poucas pessoas sabem disso. As pessoas que escreveram sobre o teatro da prisão foram principalmente praticantes escrevendo sobre seus próprios programas, e muitas dessas pessoas não são estudiosos. Eu considero que uma boa escrita acadêmica sobre o teatro deve ajudar as pessoas a imaginar performances que elas não conseguiram ver por si mesmas. Também deve fornecer análises suficientes para explicar o significado do que aconteceu nesse processo e por que é digno de ser lembrado. As pessoas que conheci nas prisões de todo o mundo me inspiraram muito. Eu acho fácil escrever sobre eles porque eu desejo com urgência que outras pessoas conheçam o talento, a criatividade, a inteligência e a compaixão extraordinárias que presenciei. No entanto, isso também torna difícil fazer esse tipo de escrita. É tão importante para mim que eu quero entender. Meus alunos também me ensinaram muito sobre esse tipo de trabalho. Admiro-os porque eles dão muito de si mesmos e têm ideias incríveis. Observá-los para aprender me lembra do quão drasticamente podemos mudar o mundo e nossas crenças sobre a justiça. Se as pessoas ao menos considerassem que todas as pessoas encarceradas são como irmãs e irmãos, nos negaríamos a perpetuar a violência sistêmica e o ódio envolvidos na grande maioria dos nossos sistemas penitenciários. 


\section{Você pode nos contar um pouco sobre o processo de criação de Doin 'Time? Quando, por quanto tempo e como você mantém vivo desde a sua primeira apre- sentação ...}

Como já disse, eu estava terminando minha graduação quando escrevi a peça em 2004. Comecei a dizer a todos que eu conhecia que meu pai estava na prisão e que eu queria escrever uma peça sobre as famílias dos prisioneiros. Descobri então que a maioria dos negros e latino-americanos que conheci na graduação tinha um membro da família na prisão e, mesmo que soubessem que meu pai estava preso, eles nunca mencionaram suas histórias familiares para mim. A proposta dessa peça lhes deu uma razão para falar sobre isso comigo pela primeira vez. Eu também comecei a me juntar a organizações que faziam trabalho ativista com as famílias e pessoas do prisioneiro voltando para casa da prisão, e conheci muitos dos meus entrevistados dessa forma. Muitas das pessoas que entrevistei eram amigos de amigos. À medida que as pessoas ouviram sobre o que estava fazendo, de repente surgiram mais pessoas que queriam fazer parte da peça do que eu tinha tempo de entrevistar. As pessoas estavam desesperadas para falar sobre o que tinha acontecido com suas famílias porque ninguém nunca antes havia perguntado. Os presidiários responderam ainda mais com entusiasmo. Coloquei um anúncio em um jornal produzido por um grupo chamado Coalition for Prisoners 'Rights (Coalização pelos Direitos dos Presos). Eles são uma organização pequena, mas altamente dedicada em Santa Fé, no Novo México, e eles enviam um boletim mensal a qualquer um preso nos Estados Unidos que se inscreva na sua lista de correspondentes. Coloquei um breve anúncio dizendo que eu era filha de um prisioneiro e estudante de teatro. Qualquer um que quisesse responder a algumas perguntas sobre seus relacionamentos com os membros da família poderia me escrever na Universidade da Califórnia. $O$ anúncio aconteceu apenas uma vez, mas recebi mais de quatrocentas respostas de homens e mulheres presos em todo o país. A maioria das cartas começava com o autor me agradecendo por perguntar o que tinha acontecido com a família dele. Algumas cartas eram vinte páginas ou mais - mesmo antes de ter enviado os escritores uma lista de perguntas para responder. A ideia de que a filha de um prisioneiro se importasse com as famílias de outros prisioneiros era tão poderosa que as pessoas me contaram coisas incrivelmente pessoais. Usei as entrevistas e as cartas como material de origem para a série de treze personagens que criei. A produção original que estreou em 2004 em San Diego, Califórnia, foi dirigida por Maria Figueroa - uma amiga minha, que foi uma orientadora gentil ao longo do processo de desenvolvimento da dramaturgia. Em 2009, outro excelente amigo e extraordinário diretor Joseph Megel me ajudou a reimaginar a peça e adicionar alguns novos monólogos. Tenho viajado desde então com esta última versão. Achei desde o início que eu estava escrevendo essa peça para mim mesma - como forma de ressignificar o isolamento que senti como filha de um pai presidiário. No entanto, minha experiência de apresentar essa a peça há treze anos é que existe uma necessidade urgente para pessoas em todo o mundo de ter conversas significativas sobre o que as prisões fizeram com suas famílias. Tive o privilégio de atuar em prisões, teatros, universidades e centros comunitários em quatro países diferentes, e em todos os luga- 
res eu conheci pessoas que precisavam de um lugar para falar sobre suas famílias. Fomos muito condicionados a pensar que a primeira e única conversa importante a respeito dos prisioneiros é sobre crime. As pessoas que conheço no público da minha peça estão muito menos interessadas em falar sobre o crime do que em descrever os efeitos a longo prazo do encarceramento no cotidiano. O que você diz às pessoas na escola quando eles pedem pra você convidar sua mãe encarcerada para uma reunião de pais e professores? Como você se senta para jantar todas as noites quando o lugar da mesa onde o seu irmão costumava sentar estava vazio? Como você explica ao seu filho que seu avô talvez nunca mais volte para casa? As prisões moldaram todos os dias da minha vida desde os quinze anos de idade, e isso é difícil de explicar para as outras pessoas que não estão vivendo o mesmo. A peça me permite ter essa conversa de uma maneira que não precise me expor ou a minha família de uma forma muito escancarada. Isso me permite comunicar com outros sobre uma experiência central para minha identidade. A peça se mantém fresca e viva depois de todos esses anos porque outras pessoas têm conexões emocionais semelhantes às histórias desses personagens. Desejo que tivéssemos tido muito mais inteligência sobre o sistema de justiça nos últimos treze anos e que minha peça tivesse se tornado irrelevante, mas, infelizmente, a necessidade desse trabalho parece apenas tornar-se mais urgente.

\section{Existe alguma história que você possa compartilhar sobre o impacto dessas performances nesses diferentes espaços?}

Em 2012, uma mulher chamada Sherrin Fitzer, que trabalha em uma prisão em Illinois, me perguntou se as mulheres presas que compunham um grupo de teatro poderiam montar minha peça. Concordei imediatamente e perguntei se eu poderia assistir à apresentação. As mulheres pediram então que eu fizesse a peça para que pudessem ver. Elas fariam outra coisa para mim em troca. O nome do grupo era Acting Out - um nome que eu amo. Elas pediram o meu texto, e depois de terem lido, decidiram escrever seus próprios monólogos sobre as visitas de suas famílias. Elas escreveram monólogos muito bons! Sherrin enviaria um e-mail para mim e eu responderia com minhas opiniões. As mulheres revisaram seus monólogos, memorizaram e ensaiaram. Enquanto isso, eu estava na Carolina do Norte, onde morava na época, ensaiando com meu diretor Joseph. Ele e eu pegamos os monólogos que as mulheres escreveram e os tecemos no meu roteiro. Então viajamos juntos para Illinois e passamos um dia e meio ensaiando na prisão com as mulheres. Minha mãe e a minha tia Nancy voaram do Texas para nos encontrar lá e ver a apresentação.

As integrantes do Acting Out tinham uma presença incrível, e atuaram de um jeito que quase me fez chorar durante toda a apresentação. Apresentamos para uma audiência de duzentas mulheres encarceradas e alguns administradores da prisão e convidados externos. Nunca vi uma audiência tão afetada por uma performance. A combinação do fato de que estávamos falando sobre as famílias dos prisioneiros e que as mulheres da prisão estavam no palco contando suas próprias histórias nos deu uma conexão profunda uns com os outros. A presença de minha mãe e tia na plateia também foi incrivelmente especial. Muitas das mulheres na audiência queriam saber 
como minha família se sentia sobre o fato de eu me levantar diante das multidões e anunciar que meu pai estava na prisão. Muitas famílias têm vergonha de seus parentes queridos encarcerados, e o fato de minha mãe e minha tia viajar para me apoiar foi muito importante. Essa experiência mudou minha vida e minha peça. Eu sinto a presença das mulheres do Acting Out comigo sempre que eu executo a peça agora, e sempre acho que a obra está incompleta porque elas não estão lá para compartilhar seus monólogos.

\section{Conte-nos um pouco sobre a experiência brasileira: de onde surgiu esse in- teresse pelo Brasil e o impacto dessas viagens para você e seus alunos.}

Vários meses depois de começar meu trabalho atual na Universidade de Michigan, a secretária do meu departamento me enviou um e-mail pedindo-me para chegar a uma reunião com um professor de teatro brasileiro. Parte da minha família é de ascendência mexicana, e honestamente pensei que estava sendo convidado para essa reunião por ser a única integrante Latina em meu departamento na época. Fiquei feliz de ir, mas não sabia nada do teatro brasileiro, exceto pelo trabalho de Augusto Boal. Quando cheguei ao encontro, fui apresentado ao professor Renato Icharahy da UNIRIO. Ele veio a Michigan como parte de uma iniciativa iniciada por nossa presidente da universidade, Mary Sue Coleman. Ela colocou uma grande quantidade de dinheiro para criar o que ela chamou de Iniciativa Brasil - uma troca em entre nossa universidade e UNIRIO. Eles precisavam de professores para começar a levar os estudantes de Michigan ao Brasil o mais rápido possível para estudar no exterior, em programas de intercâmbio. UNIRIO e Michigan têm programas de teatro fortes, então fazia sentido tentar iniciar uma troca lá. Renato tinha vindo a Michigan para ver se ele poderia encontrar algum professor interessado. Assim que ele começou a contar às pessoas em Michigan sobre o programa Teatro na Prisão na UNIRIO, meus colegas disseram que ele precisava se encontrar comigo e aprender sobre o PCAP. Em meia hora de conversa com Renato, eu concordei em levar estudantes para o Brasil durante pelo menos três anos. A universidade ofereceu a mim e a meus estudantes seis aulas de português e nos enviou para o Rio. Eu já fiz essa viagem com meus alunos cinco vezes e estou planejando voltar novamente no próximo ano. Eu sabia que o trabalho de teatro da prisão no Brasil me fascinaria porque todos os programas de teatro da prisão fazem isso comigo, mas nunca sonhei que eu estabeleceria colaborações tão significativas e prolongadas com os professores e estudantes que conheci no Brasil. UNIRIO tem um número impressionante de programas de teatro de alta qualidade que fazem um importante trabalho artístico e social em comunidades fora da universidade. As professoras Natália Fiche e Viviane Narvaes, levam estudantes a cinco prisões na cidade do Rio de Janeiro, todas as semanas, com o programa Teatro na Prisão. As professoras Marina Henriques Coutinho e Clarisse Lopes (que está na Universidade Estácio de Sá) e seus alunos fazem teatro com crianças e adultos no Complexo da Maré, no Programa Teatro em Comunidades. Estudantes do grupo "Teatro como Universo Scenico", dirigidos pelo professor Manuel Vellinho, apresentam músicas e peças curtas em um hospital público. Um grupo de idosos se reúne uma 
vez por semana com a professora Carmela Soares e seus alunos para encontros do Grupo de Teatro Renascer, e a professora Ana Achcar e seus alunos trazem alegria para um hospital público com um programa chamado Enfermaria do Riso. Todos esses notáveis grupos de teatro receberam a mim e meus alunos em nossa troca. Eles fazem isso mesmo que isso cause grandes inconvenientes, pois incluir um grande grupo de americanos que falam pouco português em um processo não é fácil. Eu sempre me preocupo que vamos perturbar o seu trabalho sensível e importante, mas eles nos perdoam nossas falhas e interrupções. Todos os anos, eles abrem as armas, as salas de aula e as oficinas para nos abraçar, e eu não poderia estar mais agradecido. Durante os três primeiros anos, levei os estudantes apenas ao Rio, mas em 2015 os professores da UNIRIO realizaram uma conferência e convidaram você para falar lá. Você disse que eu deveria visitar Florianópolis na próxima vez que eu viesse ao Brasil, então começamos a incorporar uma semana em Floripa na viagem a cada ano. Nós pudemos então participar das Oficinas Intensivas de Teatro em Comunidades, do programa de extensão da Professora Marcia Pompeo nos últimos dois anos. Também pude fazer uma conferência no I Seminário Internacional de Arte e Educação Prisional. Visitamos aulas da UDESC, vimos peças produzidas no departamento e pudemos visitar a primeira edição da Parque Gráfico- Feira de Arte Impressa. Foi uma experiência rica e gratificante para mim e meus alunos, e não podemos esperar para voltar em 2018. Levar professores e estudantes brasileiros para visitar Michigan tem sido uma parte importante da troca para mim. Nós conseguimos fazer isso apenas duas vezes. A Universidade de Michigan financia ambos os lados do intercâmbio, mas é muito mais fácil conseguir o dinheiro para levar estudantes para o Brasil do que para reunir o orçamento para trazer brasileiros para Michigan. Eu odiaria que nossa troca fosse unilateral - não adianta apenas eu e meus alunos aprendermos com vocês no Brasil a cada ano e vocês não consigam ver nosso trabalho em Michigan. $O$ fato de as universidades brasileiras terem menos recursos para apoiar essa troca não deveria impedir que possamos levar os professores e estudantes UNIRIO e da UDESC a Michigan. A adaptação brasileira da minha peça, que se chama "O visitante atrás das grades" surgiu por conta da última visita que os estudantes da UNIRIO fizeram a Michigan em 2015. Por coincidência, eu estava apresentando minha peça em Grand Rapids (uma cidade a cerca de duas horas de Ann Arbor) na época em que os brasileiros nos visitavam. A equipe do PCAP trouxe a delegação UNIRIO junto com várias vans cheias de estudantes de Michigan e um grupo de ex-presidiários para ver a peça. A Natália, responsável pelo Programa Teatro nas Prisões da UNIRIO adorou a peça e insistiu que ela precisava ser traduzida para o português. Dentro de alguns meses, dois estudantes da UNIRIO, Sergio Costa Junior e Kathleen Brauer, fizeram uma excelente tradução da peça, e Natália queria que eu fizesse tudo em português na próxima vez que eu voltasse para o Brasil. O meu português está melhorando muito, mas eu sabia que não tinha tempo nem energia para memorizar todo o texto em um novo idioma. Natália perguntou a Marina (nossa colega do Teatro em Comunidades) se ela toparia se apresentar comigo. Marina concordou, e a partir daí, com Sergio dirigindo, desenvolvemos uma adaptação trilíngue do texto. Sergio dividiu a peça para que alguns monólogos fossem realizados em português por Marina ou eu, e alguns personagens seriam tocados por nós duas simultaneamente, comigo falando Inglês e Marina fa- 
lando português. Ao invés de uma de nós traduzir a outra, eu faria o primeiro momento de um monólogo em inglês, e então Marina entraria para fazer a próxima parte do monólogo em português, e assim sucessivamente. Sergio pediu-me para traduzir um monólogo para o espanhol, porque esse personagem é um imigrante mexicano e parece mais interessante nessa língua. Não acho que nenhum de nós realmente soubesse como uma plateia que entendesse apenas português ficaria conectada à peça com tantas partes em inglês e espanhol. Eu também não sabia como meus estudantes de língua inglesa reagiriam ao espetáculo, mas todas as nossas plateias ficaram muito envolvidas e entusiasmadas. Fizemos duas vezes no Rio em 2016 - uma vez no campus UNIRIO e uma vez em uma prisão masculina. Então nos apresentamos em Floripa em 2017 no SESC-Prainha e no Rio em uma prisão de mulheres. As performances nas prisões significaram muito para mim. A nossa primeira apresentação desta peça trilíngue foi em uma prisão masculina, e eu estava convencida de que os homens deixariam de prestar atenção e ficariam aborrecidos sempre que se falasse em inglês. No fim, não foi nada disse que aconteceu. Eles estavam muito atentos, mesmo que não falassem a língua. Na discussão após a peça, eles pareciam ter entendido completamente a peça - a essência real da peça - mesmo que não compreendessem todas as palavras. As únicas prisões para homens em que eu apresentei a peça eram nos EUA, onde os homens encarcerados não têm permissão para tocar as pessoas que se voluntariam na prisão, por isso foi uma experiência nova para mim ser abraçada e beijada na bochecha pelos presidiários que tinha visto minha peça. Foi lindo o jeito que eles manifestaram muita energia e respeito por mim, Marina e Sergio (que também toca música no palco durante a peça).

A apresentação na prisão feminina foi mais difícil porque estávamos em um lugar muito alto e muitos das mulheres que queriam ver a peça não puderam entrar. Algumas delas conseguiram nos assistir através de um pequeno espaço nas barras do topo da cela, e durante toda a performance Marina e eu podíamos vê-las, esforçando-se para nos ver e nos ouvir. Foi doloroso. As mulheres também mostraram suas emoções de forma mais aberta do que os homens. Muitas delas choraram em voz alta e colocaram o rosto entre as mãos em momentos cruciais da peça. Eu lutei durante toda a peça para ficar inteira, pois foi muito intenso. Como esse lugar na prisão era muito alto, tivemos que fazer tudo muito rapidamente porque não havia espaço para o silêncio ou pausa, com tanto ruído de fundo. Foi uma das performances mais gratificantes, mas fisicamente exageradas que já fiz, e os rostos dessas mulheres ainda são vivos na minha memória.

Todas as apresentações foram muito emocionantes para mim, mas também muito desafiadoras porque eu estava falando os três idiomas no palco e trabalhando com outra atriz enquanto apresentava os mesmos personagens que faço há tantos anos. Na adaptação brasileira da peça, tive que incorporar uma energia mais esquizofrênica para representar, ouvir e encarnar personagens que conheci tão bem em inglês, mas que agora estavam em uma língua e numa estrutura diferente. Marina foi uma atriz fantástica, que sempre foi mais fundo a cada vez que apresentamos, e é um desafio fascinante jogar o mesmo personagem ao mesmo tempo com outra pessoa. Estou muito grata pela oportunidade de ter colaborado com ela, Sergio, Kathleen e Alice Cruz, que fez a cenografia, e Luan de Almeida, iluminador. Apresentar esse es- 
petáculo no Brasil tem sido tão exaustivo quanto emocionante. Estou muito agradecida por ter tido essa oportunidade.

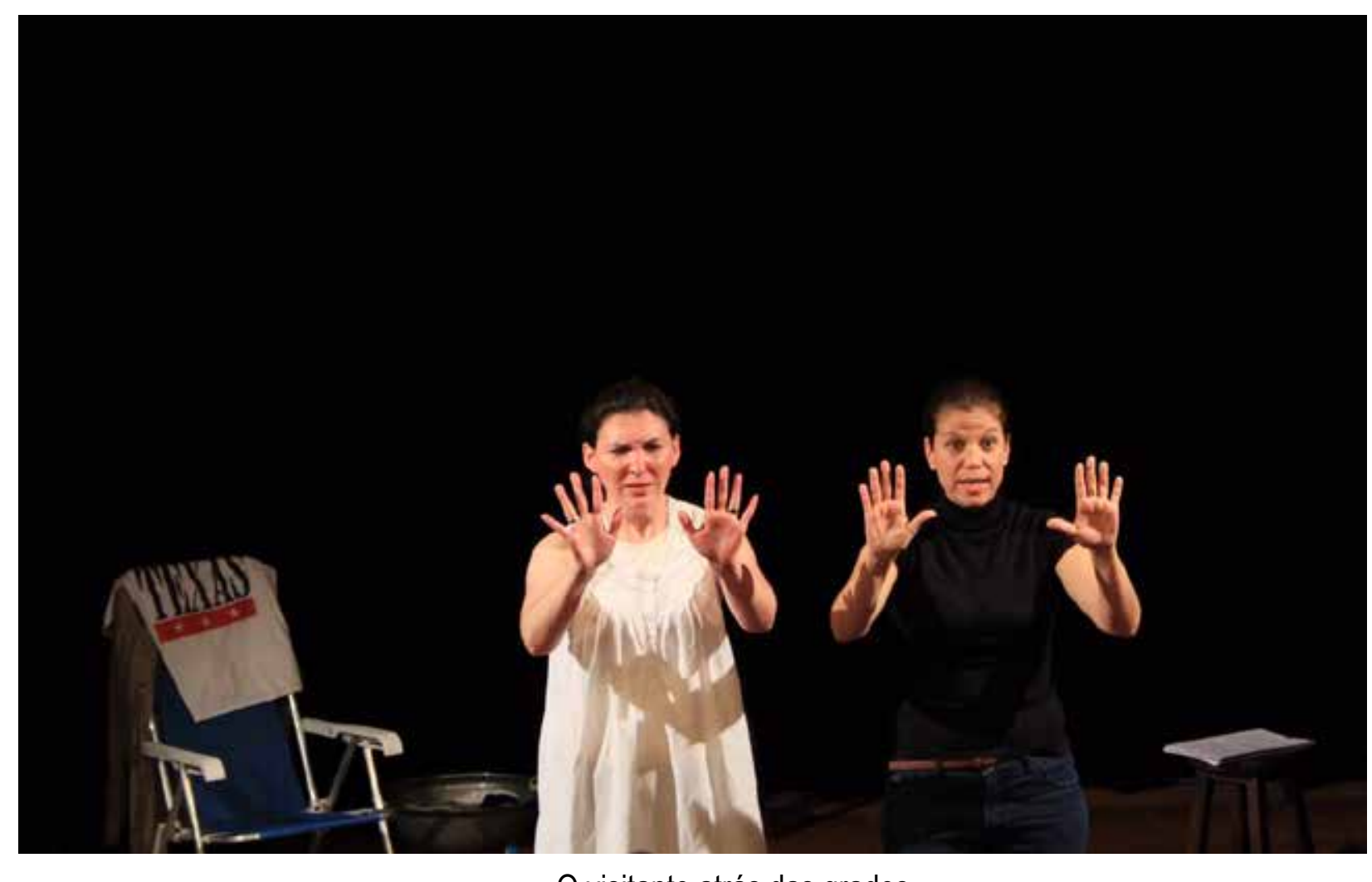

O visitante atrás das grades

Atrizes: Ashley Lucas e Marina Coutinho. Foto: Alice Cruz

Recebido em: 14/10/2017

Aprovado em: 14/10/2017 